\title{
Factors comprising Motivation to Participate in Shadow Education in West Sumatra
}

\author{
Sany Dwita ${ }^{1}$, Charoline Cheisviyanny ${ }^{2}$, Herlina Helmy ${ }^{3}$, Marwan ${ }^{4}$ \\ ${ }^{1}$ Dept. of Accounting, Faculty of Economics, Universitas Negeri Padang, Padang Indonesia, \\ $\square$ (e-mail) (sany@fe.unp.ac.id) \\ ${ }^{2}$ Dept. of Accounting, Faculty of Economics, Universitas Negeri Padang, Padang Indonesia, \\ $\square$ (e-mail) (charoline.cheisviyanny@gmail.com) \\ ${ }^{3}$ Dept. of Accounting, Faculty of Economics, Universitas Negeri Padang, Padang Indonesia, \\ $\square$ (e-mail) (lynn.herlin@gmail.com) \\ ${ }^{4}$ Dept. of Economics Education, Faculty of Economics, Universitas Negeri Padang, Padang Indonesia, \\ $\square$ (e-mail) (marwan@fe.unp.ac.id)
}

\begin{abstract}
This research aims to examine factors comprising students' motivation to participate in shadow education in West Sumatra. In particular, this research focuses on the participation of secondary school students in shadow education. Data for this research were collected by using a survey questionnaire administered to 433 private tutoring participants at 13 cities and municipalities in West Sumatra. The findings of this research show that there are five factors comprising secondary school students' participation in shadow education. Those factors are personal, family, school, private tutorial, and peer factors. The findings maybe of interest for various education stakeholders and have implications for designing classroom learning strategy and educational policies.
\end{abstract}

Keywords: shadow education, private tutoring, secondary education, learning motivation

\section{Introduction}

The impact of digital era on various aspects of education has become one of the important debates around the globe including in Indonesia. The Indonesian Ministry of Education and Culture reveals that there are four important competencies to be mastered by students in facing the digital era and the Asean Economic Community (AEC), namely, critical thinking and problem solving, creativity, communication skills, collaborative working ability (Republika, 2016). These competencies have been integrated in designing The curriculum of 2013 for basic education in Indonesia.

In the effort to improve the basic education quality, the Indonesian government implemented the education decentralization policy which has begun over a decade ago, consistent with the regional autonomy policy in Indonesia in 2001 (Alisjahbana, 2000). The policy allows greater authority at the school level to organize its own learning process (Proses Belajar Mengajar-PBM) in accordance with the national education curriculum either by adding local content subjects or incorporating local content in each subject. As such, there is a heavy load of study materials for the students to learn and a higher minimum grade (Kriteria Kelulusan Minimum - KKM) for the students to achieve to be able to pass every subject. The heavier study load combined with the limited school time create a greater demand for a support system to assist students in their learning process and achievement.

Private tutoring agencies (bimbingan belajar - private tutoring/tuition) offer the assistance needed by students. Private tutoring is defined as tutorials, complementary to the learning provided in formal schools, related to various subjects and provided by the lecturer for financial gain (Bray, 2003: 13). Thus, this definition does not include extracurricular tutorials such as sports and dancing and does not include voluntary lessons given by teachers or family members. This service is also known as shadow education because private tutoring institutions exist simultaneusly with mainstream schooling and 'shadow' the regular school system (Bray, 2014). Indeed, the curriculum of shadow education changes 
following the changes in the formal school curriculum. The terms private tutoring and shadow education are used interchangebly in this research.

Students' participation in shadow education has gained increasing interest from researchers due to its tremendous growth. A survey reported that two-thirds of families in Asia Pacific countries spend their income on shadow education (Mastercard, 2013). Countries with the biggest spending in shadow education are India (54 percent), Taiwan (52 percent), dan Thailand (52 percent). In East Asian countries such as Korea and Japan, private tutoring has been perceived as an inevitable need even in low-income families (Bray \& Kwo, 2013; Bray et al., 2014). In developed county such as United Kingdom, Sutton Trust reports that the number of state school students participating in shadow education is 42 percent in London. Whereas, 25 percent of state school students in England and Wales join shadow education in 2016 compared to 18 percent in 2005 (The Guardian, 2016). Likewise, in delveloping countries such as Egypt, India, and Malta, it was reported that one-third of students participate in private tutoring (Bray, 2003).

In Hong Kong, Bray et al. (2014) show that the $9^{\text {th }}$ and $12^{\text {th }}$ year students and their parents considered paying for shadow education as an investment, "buying" good results in national exams and, consequently, a better future. The study also show a negative impact of shadow education, strengthening the social gap in formal education where wealthy families have a bigger opportunity to participate and to spend more on private tutoring than the less-wealthy households (Bray et al., 2014).

In Malaysia, it was reported that students' participation in shadow education is due to the teachers' in ability to provide sufficient attention to every students in the commonly large classroom. Indeed, most parents believed that they have no choice but to send the students to private tutoring to help them understand the school materials and pass the exam (Anonymous, 2014). Further, Liang and Awang (2010) show that 110 elementary and high school students in Perak Malaysia reported indicate that their peer provide the greatest motivation to participate in shadow education. The students also reported that various aspects related to their parents and teachers at school provide the next motivation force for them to join private tutoring (Liang \& Awang, 2010).

It is undeniable that shadow education offers a positive outcome such as promoting and improving students' learning as well as offering productive activities after school hours (Bray, 2003; Bray \& Suso, 2008). In contrast, private tutoring presents issues such as distortions to the main curriculum and creating additonal burden on students. The shadow education activity can interrupt lessons in school and produce fatigue for students and teachers. Further, a worst-case scenario is reported in the form of extortion where teachers intentionally only teach some part of the curriculum at school and require students to pay for learning the rest of the material in a private tutorial after school hours (Bray, 2003: 13).

Shadow education is also an important phenomenon in various regions in Indonesia. Indonesia household spent 17 percent of their income on shadow education (Mastercard, 2013). The Directorate General of Nonformal and Informal Education of The Ministry of Education and Culture reports a more that 50 percent growth of private tutoring in the country, there are 1,721 institutions in 2010 compared to 1,135 institutions in 2005 (Bank of Indonesia, 2010). In the Province of West Sumatra, it is reported that there are 85 registered private tutoring institutions (Bank of Indonesia, 2010). Private tutoring is appered to be a necessity, it is indicated by news report that it is common for students to go to private tutoring straight after school and study there up to the evening. It is indeed indicates the comparable amount of time the students spend between school and private.

The earlier discussion show that several studies have been undertaken in other countries to gain understanding on the shadow education phenomenon. Few studies in Indonesia have examined the influence of private tutoring to students' learning performance. However, there is a lack of research in the context of Indonesia focusing on the root cause of students' participation in shadow education. As such, this research aims to contribute to the literature by analysing students' participation in shadow edcation in West Sumatra. In particular, this study formulate a research question as follows: What 


\section{factors comprising secondary school students' moivation to participate in shadow education in West Sumatra?}

A preliminary survey was conducted to 107 students in four high schools in Padang. The results show that more than 50 percent students participate in shadow education. There are at least three aspects that motivate students for shadow education, namely, the flaw in the formal education quality, the diminishing responsibility of parents in their children learning, and the nature of study materials (Tobing, 2010). The poor quality of formal education is seen from the fierce competition to anter favorite schools, the rapid change of school curriculum, and limited time compared to study materials.

In this research, motivation is defined as the effort that forces someone to do something (Sardiman, 2012). Motivation can be said as the chief reason from within an individual to perform particular activities to attain goals. In the context of this research, learning motivation is an innermost process that pushes and offers direction to an individual to learn. This will be reflected in the ability to seize initiative, to devote commitment, perseverance, strong will, independent learning, endurance and a craving for success (Baharudin, 2007 and Slameto, 2003).

It is suggested that learning motivation is comprised of internal (intrinsic) and external (extrinsic) factors (Hamalik, 2001; Uno, 2006). Intrinsic motivation is a living motivation in individuals and useful in productive functional learning situations. The most relevant intrinsic motivation is individual factors such as the desire for better grade and the need to be with close friends (Barrow \& Lochan, 2012; Byun, 2014). Whereas, the extrinsic motivation is a motivation that exists due to external stimuli. Extrinsic motivation is still required in schools, because teaching in schools does not all appeal to students according to the needs of the students. The extrinsic motivation can be instigated from various external aspects of learning such as important aspect related to the students' parents and family as well as their teachers and schools (Bray, 2003; Bray, 2012).

A more relevant study by Kurniawati and Cheiviyanny (2015) reports that individual, school, and parents provide motivating factors for state high school students in Padang to involve in shadow education. Aspects of the individual factor are desire for a better grade, the parents influence, and the peer influence. Aspects from school factor are the distant relation between students and teachers, the inflexibility of the teachers, and the teachers' ignorance on learning issues faced by students. While aspects of family factor are the parents' ability to pay, fulfiling parents' demand and following the footsteps of their siblings. The students also reported that they experience an improvement in their grade due to private tutoring in the expense of rest hours, extracurriculer activities and hobbies (Kurniawati \& Cheiviyanny, 2015). The study, however, only focused on high school students in the city of Padang. As such, the current research contributes to the literature by examining the shadow education phenomenon in the larger scope of West Sumatra involving secondary students, namely, junior high schools and high scool students.

The remainder of this paper is organized as follows. The next section presents the research methods and is followed by results and discussion. The final section concludes the paper and discussed the implications.

\section{Methods}

As explained earlier, this research focuses on examining factors comprising motivation of secondary schools students to participate in shadow education in West Sumatra. Based on prior literature, a questionnaire was developed to eliciting students' response on 52 statements that explain their participation in shadow education. The students' responses were measured by using a 5-point Likert scale (strongly agree=1, strongly disagree=5). The 52 statements in the questionnaire were related to individual, family and school aspects that comprise students's motivation in shadow education as presented in Table 1. 
Table 1 Items comprising the research questionnaire

\begin{tabular}{|c|c|c|c|c|}
\hline No & Factors & Indicators & No. of items & References \\
\hline 1. & Individual & $\begin{array}{l}\text { - Desire to have good } \\
\text { grades, } \\
\text { - Desire to be close to peers, } \\
\text { - Interesting promotion from } \\
\text { private tutoring services. }\end{array}$ & 22 & $\begin{array}{l}\text { Barrow dan Lochan } \\
\text { (2012) }\end{array}$ \\
\hline 2. & School & $\begin{array}{l}\text { - School learning quality, } \\
\text { - School ranking, } \\
\text { - Clasroom learning process, } \\
\text { and } \\
\text { - Classroom size }\end{array}$ & 16 & $\begin{array}{l}\text { Bray (2003), } \\
\text { Bray et al. (2012) }\end{array}$ \\
\hline 3. & Parents & $\begin{array}{l}\text { - Parents occupation, } \\
\text { - Parents income, } \\
\text { - Family size, } \\
\text { - Parents education }\end{array}$ & 14 & $\begin{array}{l}\text { Bray (2003), } \\
\text { Dang dan Rogers (2009), } \\
\text { Bray et al. (2014) }\end{array}$ \\
\hline
\end{tabular}

The Indonesian Ministry of Education and Culture (2016) reported that there are 484,320 secondary school students in West Sumatra. Their level of participation in shadow education can be estimated based on the report that around 70 percent students participate in private tutoring (Bank of Indonesia, 2010). As such, it is estimated that the total population of shadow education's partisipants in West Sumatra is 339,024 secondary school students.

Table 2 Details of the questionnaire distribution

\begin{tabular}{lllc}
\hline No. & $\begin{array}{c}\text { City/Municipality } \\
\text { (Kota/Kabupaten) }\end{array}$ & $\begin{array}{c}\text { Number PT } \\
\text { Institutions }\end{array}$ & $\begin{array}{c}\text { Questionnaires } \\
\text { Distributed }\end{array}$ \\
\hline I. & Having more than 15 PT institutions: & & \\
\hline 1. & City of Padang & 23 & 141 \\
\hline II. & Having 5 to 15 PT institutions: & & \\
\hline & Kabupaten Padang Pariaman & 7 & 27 \\
\hline$\quad$ Kabupaten Pasaman & 5 & 26 \\
\hline & Kabupaten Tanah Datar & 6 & 22 \\
\hline & City of Bukittinggi & 8 & 33 \\
\hline & City of Payakumbuh & 5 & 30 \\
\hline$\quad$ City of Solok & 7 & 30 \\
\hline II. & Having less than 5 PT institutions: & & \\
\hline 1 & Kabupaten Dharmasraya & 1 & 25 \\
\hline 2 & Kabupaten 50 Kota & 4 & 20 \\
\hline 3 & City of Padang Panjang & 4 & 22 \\
\hline 4 & City of Sawahlunto & 3 & 27 \\
\hline 5 & Kabupaten Pesisir Selatan & 3 & 10 \\
\hline 6 & Kabupaten Solok & 1 & 20 \\
\hline & & & 433 \\
\hline & Respond Rate & & $100 \%$ \\
\hline
\end{tabular}

The data were collected using a survey questionnaire administered to 433 secondary school students participating in shadow education in 13 cities/municipalities in West Sumatra in 2017. The sample size was decided based on the Slovin formula with 5 percent error. Given the vastness of the study site, the number of questionnaires administered to each city/municipality was decided based on the number of registered private tutoring institutions in the particular city/municipality as shown in Table 2. The students were chosen as respondents based on accidental sampling technique, i.e. students who come and attend private tutoring at the time of data collection. 
The data collected were analyzed using Confirmatory Factor Analysis (CFA). This analysis involves the process of eliminating several items of questionnaires that are perceived as irrelevant as a motivating factor of students' participation in the private tutoring. Finally, this analysis will indicate the relevant items as the motivating factor for the students' participation in private tutoring.

\section{Results and Discussion}

A preliminary analysis was conducted on the data and the results show that 433 junior and high school students in this study perceive that 11 items that are not relevant in forming their motivation to participate in shadow education. These 11 items were gradually eliminated in the factor analysis process. With regards to the personal-related factor in the questionnaire, there are 5 items out of a total of 22 items perceived as irrelevant to the students participation. Those irrelevant items are: most of my friends in the class join private tutoring, my friends invite me to join private tutoring, my friends who participate in private tutoring get better grades, preference to study at private tutoring rather than at school, and the embarassment when receving bad grades at school.

As to the school-related factor in the questionnaire, there are 2 items out of a total of 16 items that are perceived to be irrelevant to motivation for joining private tutoring. Those 2 items are, namely, teachers do not discuss tasks assigned in the classroom and teachers in schools who are unable to discuss difficult material.

For the family-related factor in the questionnaire, there are 4 items from 14 items perceived as irrelevant by students as motivating factor for private tutoring. Those 4 items are their parents ability to pay the entire cost of private tutorial, parents' preference for students to join private tutoring rather than other activities, the parents' desire for students to choose college major that is in conflict with the students' preferrence, the desire not to lose competition with brothers/sisters who get better grades.

Furthermore, the results of factor analysis showed that the remaining 41 items can be grouped into 12 factors that encourage students to participate in shadow education. Table 3 below shows the results of factor analysis which yielded 12 factors.

Table 3 shows that each loading factor of the 12 factors formed is in the range 0.5-0.8. Hair (2006) explains that loading factor between $0.5-0.6$ indicates that the factor is quite dominant in encouraging students to follow the private tutorial, while loading factor between $0.6-0.8$ indicates that the factor is dominant in comprising students motivation to participate in the private tutorial.

Table 3 Results of factor analysis

\begin{tabular}{|c|c|c|c|}
\hline No & Factors & $\begin{array}{l}\text { Items Comprising Motivation } \\
\text { for Participation in Shadow Education }\end{array}$ & $\begin{array}{l}\text { Loading } \\
\text { factor }\end{array}$ \\
\hline 1 & Teacher & $\begin{array}{l}\text { 1. In school, teachers do not pay attention to student learning } \\
\text { difficulties } \\
\text { 2. It is difficult to learn / ask questions to teachers after school } \\
\text { hours } \\
\text { 3. Teachers cannot complete discussion on difficult materials } \\
\text { 4. Teachers do not have enough question banks to be discussed } \\
\text { 5. The teaching and learning process in school is boring } \\
\text { 6. Teachers are not close to students } \\
\text { 7. Teachers seem uncomfortable if students often ask questions } \\
\text { in class }\end{array}$ & $\begin{array}{l}0.623 \\
0.743 \\
0.723 \\
0.644 \\
0.743 \\
0.635\end{array}$ \\
\hline 2 & $\begin{array}{l}\text { Personal } \\
\text { ambitions }\end{array}$ & $\begin{array}{l}\text { 1. I want to make my parents happy } \\
\text { 2. I want to be accepted in a college major that I desire } \\
\text { 3. I do not want to lose in competition with my classmates } \\
\text { 4. I want to be the outstanding student in the class } \\
\text { 5. I do not want to make my parents sad if I fail or if I get bad } \\
\text { grades }\end{array}$ & $\begin{array}{l}0.677 \\
0.616 \\
0.700 \\
0.630 \\
0.618\end{array}$ \\
\hline
\end{tabular}




\begin{tabular}{|c|c|c|c|}
\hline No & Factors & $\begin{array}{l}\text { Items Comprising Motivation } \\
\text { for Participation in Shadow Education }\end{array}$ & $\begin{array}{l}\text { Loading } \\
\text { factor }\end{array}$ \\
\hline \multirow[t]{4}{*}{3} & \multirow{4}{*}{$\begin{array}{l}\text { Learning } \\
\text { process in the } \\
\text { private } \\
\text { tutoring }\end{array}$} & $\begin{array}{l}\text { 1. I prefer to participate in external private tutorial than private } \\
\text { tutorial session with the teacher in school }\end{array}$ & 0.661 \\
\hline & & $\begin{array}{l}\text { 2. The heavy load of homework will be easily finished during } \\
\text { private tutorial }\end{array}$ & 0.716 \\
\hline & & $\begin{array}{l}\text { 3. School hours are not enough to complete all the materials so } \\
\text { it must be learned in private tutorial }\end{array}$ & 0.739 \\
\hline & & $\begin{array}{l}\text { 4. The problems discussion in school is complicated while it is } \\
\text { shorter and clearer in the private tutorial }\end{array}$ & 0.693 \\
\hline \multirow[t]{4}{*}{4} & \multirow{4}{*}{$\begin{array}{l}\text { Parents' } \\
\text { desires }\end{array}$} & 1. My parents want me to get good grades & 0.651 \\
\hline & & 2. My parents embarrass if I get bad marks & 0.568 \\
\hline & & 3. My parents want me to continue to the higher education & 0.699 \\
\hline & & 4. My parents are sad if I fail & 0.705 \\
\hline \multirow[t]{4}{*}{5} & \multirow{4}{*}{$\begin{array}{l}\text { Private } \\
\text { tutoring's } \\
\text { promotions }\end{array}$} & 1. I am interested in the promotions offered by the private & 0.800 \\
\hline & & tutorial & 0.749 \\
\hline & & 2. The programs offered by private tutorial are interesting & 0.789 \\
\hline & & 3. Private tutorials provide attractive discounts & \\
\hline \multirow[t]{6}{*}{6} & \multirow{6}{*}{$\begin{array}{l}\text { Private } \\
\text { tutoring's } \\
\text { instructors }\end{array}$} & 1. Private tutorials have a huge number of exam problem & 0.605 \\
\hline & & examples & 0.710 \\
\hline & & 2. The teaching and learning process in the private tutorial is & 0.614 \\
\hline & & fun & 0.704 \\
\hline & & The instructor understands my learning difficulties & \\
\hline & & 4. The instructor teaches me in a fun way & \\
\hline \multirow[t]{2}{*}{7} & \multirow{2}{*}{$\begin{array}{l}\text { Personal } \\
\text { desires }\end{array}$} & 1. I want to get good marks & 0.810 \\
\hline & & 2. I want to pass the exam & 0.715 \\
\hline \multirow[t]{4}{*}{8} & \multirow{4}{*}{$\begin{array}{l}\text { Parents' } \\
\text { suggestions }\end{array}$} & 1. My parents ask me to participate in private tutorial & 0.590 \\
\hline & & 2. My parents think it is important to participate in private & 0.703 \\
\hline & & tutorial & 0.677 \\
\hline & & 3. My siblings also participate in private tutorial & \\
\hline \multirow[t]{3}{*}{9} & \multirow[t]{3}{*}{$\begin{array}{l}\text { Parents' } \\
\text { busyness }\end{array}$} & $\begin{array}{l}\text { 1. My parents are busy, so they cannot help me doing my } \\
\text { homework }\end{array}$ & 0.748 \\
\hline & & 2. My parents do not understand the school materials & 0.632 \\
\hline & & $\begin{array}{l}\text { 3. There is nobody at home in the afternoon, so it is better to } \\
\text { participate in private tutorial rather than being lonely }\end{array}$ & 0.563 \\
\hline \multirow[t]{2}{*}{10} & \multirow[t]{2}{*}{ Peers } & 1. I like to study with friends in private tutorial & 0.738 \\
\hline & & 2. I like to meet new friends in private tutorial & 0.771 \\
\hline \multirow[t]{2}{*}{11} & \multirow{2}{*}{$\begin{array}{l}\text { Teachers' } \\
\text { suggestions }\end{array}$} & 1. Teachers ask me to participate in private tutorial & 0.707 \\
\hline & & 2. Teachers offer me extra lessons after school hours & 0.771 \\
\hline \multirow[t]{2}{*}{12} & \multirow{2}{*}{$\begin{array}{l}\text { Academic } \\
\text { achievement }\end{array}$} & 1. My grades were not good & 0.821 \\
\hline & & I cannot understand the lesson explained by teachers & 0.514 \\
\hline
\end{tabular}

Some of the 12 factors in Table 3 can be further merged to finally resulted in five factors. Those are personal/ individual factors, family/parents factor, school/teacher factor, private tutorial factor, and peer factor. First, the individual factor is one of the factors that encourage students to join private tutoring. This factor is a combination of personal ambitions, desires, and academic achievement. The findings are consistent with Bray et al (2014) who found that individual factors determine the demand for private tutorial. The same thing applied to students in West Sumatra. The students' ambition to become class champions or to be accepted into a college or to make parents happy encourages them to follow the private tutorial. Likewise, with their desire to get good grades or pass the exam. The lack 
understanding of teachers' explanations in schools that cause poor grades, also encourages students to participate in shadow education.

The next factor that encourages students to participate in private tutorial is the factor of family/parents. This factor is a combination of desire, suggestions, and busy parents. This is in accordance with research Bray et al (2014) and Liang and Awang (2010). Bray et al. (2014) find that students and their parents have a high hope to invest funds in the hope of "buying" good results on national exams. While Liang and Awang (2010) found that parents are the second factor motivating students' participation in the private tutoring. Parents, who feel incompetent to help with the students' learning at home, due to their lack of understanding of lessons or being busy, encourage their children to participate in shadow education especially if they are able to afford it.

The results of this study indicate that parents have a desire for their children to have a good marks and to be able to continue their education to a higher level. Parents encourage their children to participate in shadow education because they feel it can realize their desires, combined with their other childrens' participation in shadow education. Consistent with Kurniawati and Cheisviyanny (2015), the findings of this research show that the busy parents are the driving force for students to join shadow education. Busy parents will encourage their children to join private tutorial in the reason of they do not have time to help their children's with the school lessons. Another reason is they feel secure that enrolling their children in private tutoring will prevent their children from wandering out or doing negative activities. All these reasons encourage students to participate in private tutoring.

School/teacher factor is the next factor. The research findings are consistent with Bray et al. (2014) and Liang and Awang (2010). In fact, our respondents stated that the reasons they follow the private tutorial are because teacher does not pay attention to the students' learning difficulties, it is difficult to have the opportunity to learn/ask the teacher after school hours, the teacher in school cannot finish the difficult material discussion, the teacher does not have question banks to be discussed, teaching process in school is boring, Teachers are not close to students, Teachers do not seem comfortable if students often ask in class.

The findings are, however, in contrast to Anonymous (2014) that reported that teachers consider they contribute positively to student learning process. In addition, teachers are willing to provide additional lessons for students. Teachers reported that their students did not hesitate to approach them when they had difficulty understanding the lesson. In particular, teachers consider private tutoring as a formal school complement that enhances students' abilities and helps them succeed in school exams.

The private tutoring factor itself also contribute to students' choise of private tutoring institutions. This factor is a combination of learning process, the promotion, and the instructor aspects. Anonymous (2014) found private tutorial helps students develop learning strategies, build confidence and encourage critical thinking. Based on the findings, the it was concluded that student participation in private tutorial does not indicate public distrust of the formal school system. In contrast, respondents in this research reveal that they prefer private tutoring because the instructor discuss lesson problems in a clear and concise way, unlike at schools where teachers discuss lesson problems in a complex and long explanation. Teachers like to assign a lot of homework while class duration are not sufficient to explain all lesson materials. As such, assistance is very much needed by students to be able to understand all the lesson materials. Instructors in private tutoring also play an important role in motivating students joining shadow education. The findings show that the instructors tend to understand the students' learning issues and apply an interesting teaching method. Further, private tutoring institutions have collected a large number of problem examples.

Promotion offered by the private tutoring is also a motivating factor for students to join shadow education. The findings show that interesting promotions from private tutoring agencies motivate students to join private tutoring. These promotions include large discount offers, money back guarantees, and the high number of the agencies previous sudents that accepted into state university. 
Finally, peer is also a motivating factor for students to participate in shadow education. The findings of this study are in line with Barrow and Lochan (2012) that peer invitation encourages students to participate in private tutoring. Similarly, Liang and Awang (2010) find that peer factor has the greatest influence on student participation in shadow education. The findings indicate that students are eager to be able to study with their peers so that they can discuss the lesson and exchange ideas. The discussion with peers help students to easily understand their lessons more and allow them to help others who have difficulties in understanding the lesson and consequently improve their understanding and study outcomes.

\section{Conclusions}

The decentralization policy of education which initially aims to improve the quality of education by allowing a greater authority to schools is believed to have an impact on students learning process. A large number of students seek study assistance from private tutoring agencies (or shadow education) to be able to fulfill the minimum grade (Kriteria Ketuntasan Minimum-KKM) required to pass their school subjects. The research question of this is research raised a resre phenomenon of shadow education raises because private tutoring was reported to emphasis in teaching solusions without explaining important concepts to students. This undermines the student's concept and analysis power. This study aims to analys factors motivationg students to participate in shadow education in West Sumatra.

The data for this resaerch were collected by a survey questionnaire to 433 secondary school students in 13 cities/municipalities in West Sumatra. The findings of this study show factors comprising students' participation in shadow education, namely, individual, family, school, private tutoring and peer factors. The findings of this research contribute to our understanding of shadow education phenomenon in West Sumatra. The findings maybe of interest for various education stakeholders and have implications for designing classroom learning strategy and educational policies.

\section{References}

Alisjahbana, Armida S. (2000). Otonomi daerah dan desentralisasi pendidikan. Retrieved from web.iaincirebon.ac.id/ebook/main/social-welfare on 2 April 2015.

Anonymous. (2014). Teachers' perceptions on the effectiveness of private tutoring in Malaysia. Revue internationale d'éducation de Sèvres [En ligne], Colloque : L'éducation en Asie en 2014: Quels enjeux mondiaux?, mis en ligne le 27 mai 2014, consulté le 24 mars 2015. Retrieved from http://ries.revues.org/3801

Baharudin \& Wahyuni, Esa Nur. (2007). Teori Belajar dan Pembelajaran. Yogyakarta: Ar- Ruz Media.

Bank of Indonesia. (2010). Pola Pembiayaan Usaha Kecil (PPUK) Komoditas Jasa Bimbingan Belajar. Retrieved from http://www.bi.go.id/id/umkm/kelayakan/pola-pembiayaan/perdagangan /Documents/ffe3421401fd4332beca78a62c41bc99Bimbel.pdf on 2 April 2015.

Barrow, D. A., \& Lochan, S. N. (2012). Supplementary tutoring in Trinidad and Tobago: Some implications for policy making. International Review of Education, 58(3), 405-422.

Bray, Mark. (2003). Adverse effects of private supplementary tutoring: Dimensions, implications band government responses. International Institute for Educational PlanningInternational Institute for Educational Planning, UNESCO. Retrieved from: http://www.unesco.org/iiep

Bray, Mark \& Suso, Emmanuelle. (2008). The challenges of private supplementary private tutoring: Global patterns and their implications for Africa. Association for the Development of Education in Africa (ADEA) Biennale, Maputo, Mozambique, 5-9 Mei 2008.

Bray, Mark \& Lykins, Chark. (2012). Shadow Education. CERC Monograph Series in Comparative and International Education and Development No. 9. Philippines: Asian Development Bank.

Bray, M., Zhan, S., Lykins, C., Wang, D., \& Kwo, Ora. (2014). Differentiated demand for private supplementary tutoring: Patterns and implications in Hong Kong secondary education. Economics of Education Review, 38, 24-37. 
Dang, Hai-Anh \& Rogers, F. Halsey. (2008). The growing phenomenon of private tutoring: Does it deepen human capital, widen inequalities, or waste resources? The World Bank Research Observer, 23(2), 161-200.

Forbes. (2012, 30 October). Global private tutoring market will surpass $\$ 102.8$ billion By 2018. Retrieved from http://www.forbes.com/sites/jamesmarshallcrotty/2012/10/30/global-private-tutoringmarket-will-surpass-102-billion-by-2018/

Gronlund, Norman E. (1976). Measurement and Evaluation in Teaching. New York: Macmillan Publisher. Info Kursus. (2015). Retrieved from www.infokursus.net/datakursus.

Joice, B., Weill, M., \& Calhoun, E. (2009). Model of Teaching (Model-Model Pengajaran). Alih Bahasa: Achmad Fawaid dan Ateilla Mirza. Yogyakarta: Pustaka Pelajar

Kurniawati, T. \& Cheisviyanny, C. (2015). Shadow Education: Faktor Penentu Permintaan dan Implikasinya (Studi pada siswa SMA Negeri di Kota Padang). Working Paper.

Lee, C. J., Park, H. J., \& Lee, H. 2009. Shadow education systems. In G. Sykes, B. Schneider, \& D. N. Plank (Eds.), Handbook of education policy research, pp. 901-919. New York: Routledge for the American Educational Research Association.

Liang, Lim Nguk \& Awang, Mohd. Isha. 2010. Faktor guru, ibu bapa dan rakan-rakan dengan amalan tuisyen pelajar: Satu tinjauan awal. Retrieved from http://www.medc.com.my/medc/ seminar_medc/fromcd/pdf/84.

Mastercard. (2013). Two thirds of Asia/Pacific parents spending on extra tuition for kids: MasterCard survey. Retrieved from http://newsroom.mastercard.com/press-releases/two-thirdsofasiapacific -parents-spending-on-extra-tuition-for-kids-mastercard-survey/

Nath, Samir Ranjan. (2008). Private supplementary tutoring among primary students in Bangladesh. Educational Studies, 34(1), 55-72, DOI: 10.1080/03055690701785285.

Purwanto, M. Ngalim. (2007). Psikologi Pendidikan. Bandung: Remadja Rosdakarya Offset.

Republic of Indonesia. Law No. 20 Year 2003 on National Education System.

Republika. (2016, 21 January). Empat kompetensi yang perlu dimiliki di era digital. Retrieved from http://www.republika.co.id/berita/pendidikan/eduaction/16/01/21/o1a0by280-empatkompetensi-yang-perlu-dimiliki-di-era-digital.

Shaleh, Abdul Rahman; et al. (2004). Psikologi Suatu Pengantar. Jakarta: Prenada Media.

Slameto. (2003). Belajar dan Faktor-Faktor yang Mempengaruhinya. Jakarta: Rineka Cipta.

Statistical Bureau Agency (Badan Pusat Statistik-BPS ). (2014). Sumatra Barat dalam Angka Tahun 2014. Retrieved from www.sumbar.bps.go.id on 25 April 2015.

Sudjana, Nana. (2003). Penilaian Hasil Proses Belajar Mengajar. Bandung: PT. Remaja Rosdakarya.

Suhendi. (2012). Bimbingan belajar sebagai pelengkap sekolah. Koran Pikiran Rakyat, Senin 9 April 2012.

Sukardi, Dewa Ketut. (2000). Pengantar Pelaksanaan Program Bimbingan dan Konseling. Jakarta: Rineka Cipta.

Supriyono, RA. (2000). Sistem Pengendalian Manajemen. Yogyakarta: BPFE.

The Guardian. (2016, 26 October). Out of the classroom: The ex-teachers meeting the need for private tutors. Retrieved from https://www.theguardian.com/small-business-network/2016/oct/26/out-ofclassroom-ex-teachers-meeting-need-for-private-tutors

Tobing, Ratna Lumban. (2010). Menjamurnya lembaga bimbel. Retrieved from http://ratnalumbantobing.blogspot.com/2013/01/mengkritisi-menjamurnya-bimbel-di.html on 2 April 2015. 